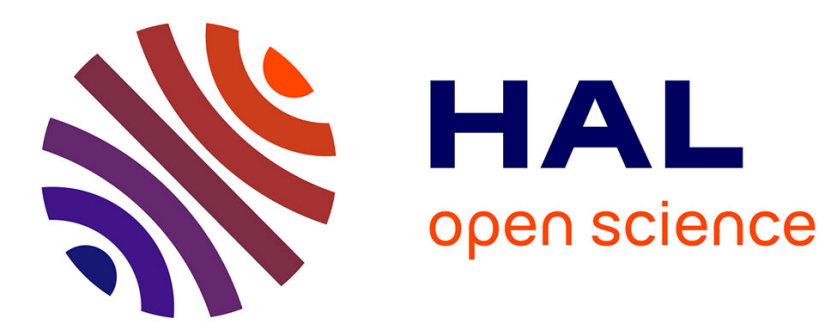

\title{
THE DIFFUSIVITY OF NONLINEAR WAVE PROPAGATION IN PIPES
}

Cornelius Shih

\section{To cite this version:}

Cornelius Shih. THE DIFFUSIVITY OF NONLINEAR WAVE PROPAGATION IN PIPES. Journal de Physique Colloques, 1979, 40 (C8), pp.C8-53-C8-55. 10.1051/jphyscol:1979811 . jpa-00219516

\section{HAL Id: jpa-00219516 https://hal.science/jpa-00219516}

Submitted on 1 Jan 1979

HAL is a multi-disciplinary open access archive for the deposit and dissemination of scientific research documents, whether they are published or not. The documents may come from teaching and research institutions in France or abroad, or from public or private research centers.
L'archive ouverte pluridisciplinaire HAL, est destinée au dépôt et à la diffusion de documents scientifiques de niveau recherche, publiés ou non, émanant des établissements d'enseignement et de recherche français ou étrangers, des laboratoires publics ou privés. 
THE DIFFUSIVITY OF NONLINEAR WAVE PROPAGATION IN PIPES,

Cornelius C. SHIH

Mecharical Engineering Department The University of Alabama in Huntsville Huntsville, Alabama 35807

Rẽsumé. - Les distributions de vitesse dans le temps et dans l'espace le long de tuyaux de $7.62 \mathrm{~cm}$ et $2.54 \mathrm{~cm}$ de diamètre et d'une 1 ongueur de $64 \mathrm{~m}$ produites par des ondes nonlinéaires de pression d'intensités différentes ont été mesurées et comparées avec les résultats thêoriques unidimensionnels obtenus par la méthode des caractéristiques avec ou sans le terme de diffusion dans le but de déterminer les caractéristiques d'atténuation de l'onde de propagation. Les données ont été analysées afin d'établir la relation entre le rapport de flux d'énergie et la distance dans le tuyau exprimée en fonction du coefficient d'atténuation $\alpha$ et de la diffusibilité. On a montré que ces parètres caractéristiques sont fonction de la géométrie du tuyau : diamètre, longueur, et rugosité relative.

Abstract. - Temporal and spacial velocity distributions along the pipes of $7.62 \mathrm{~cm}$ and $2.54 \mathrm{~cm}$ in diameter and $64 \mathrm{~m}$ in length produced by non-linear pressure waves of various intensities were measured an compared with onedimensional theoretical results obtained by the method of characteristics with and without the diffusion term for the purpose of determining the attenuation charactersitics of the wave propagation. Data were analyzed for the relationship between the energy flux ration and pipe distance in terms of attenuation coefficient $\alpha$ and diffusivity $\delta$. These characteristic parameters are determined to be the function of pipe geometries such as diameter, length and relative roughness.

1. INTRODUCTION. - Experimental studies $/ 1 /, / 2 /$, /3/ of attenuation characteristics of non-linear pressure waves of progressive type propagating in pipes of $7.62 \mathrm{~cm}$ and $2.54 \mathrm{~cm}$ in diameters and of various lengths up to $64 \mathrm{~m}$, were measured in temporal and spacial velocity profiles and compared with theoretical results obtained by the method of characteristics with and without the isentropic assumption.

Non-linear attenuation of the pressure waves were presented in terms of attenuation coefficient $\alpha$ and diffusivity $\delta$, based on the experimental results. The energy flux was determined from the velocity profiles measured at various sections along the pipes, and the decay of the total energy flux was related to the space coordinate and pipe size.

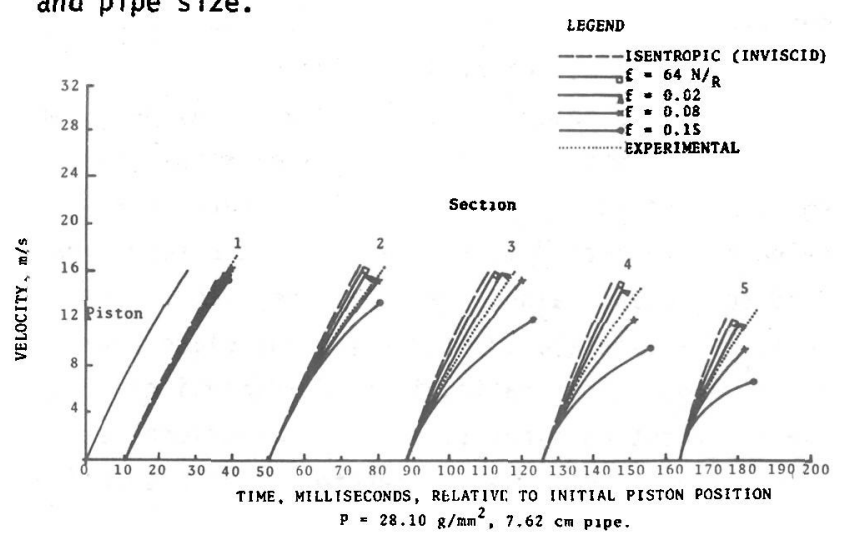

Experimental Data Presentation. - Experimental data of velocity profiles were measured at the center of each of five sections located 3.60 ; $16.62 ; 29.45 ; 45.44 ; 55.40 \mathrm{~m}$ from the pipe inlet, respectively, in the pipes of 7.62 and $2.54 \mathrm{~cm}$ in diameter. Two pressure waves of progressive type applied to each pipe for the timedependent measurement of velocity profiles with hot-wire anemometers were presented for comparison in this paper.

Figures 1 to 4 shows time-dependent velocity profiles measured at the five pipe sections in the $7.62 \mathrm{~cm}$ (3-in.) and $2.54 \mathrm{~cm}\left(1-i_{\text {. }}\right)$ pipes for two pressure waves produced with nominal burst pressures of 28.10 and $56.20 \mathrm{~g} / \mathrm{mm}^{2}$. Also presented are

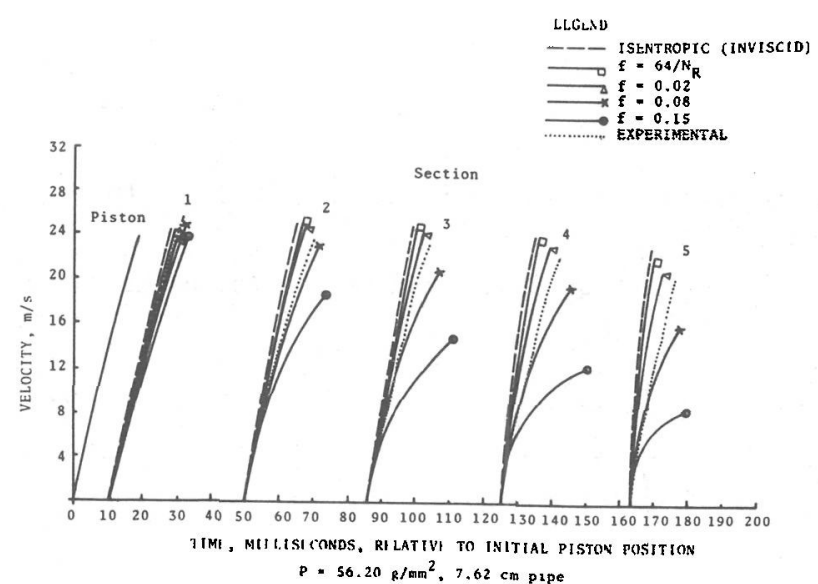



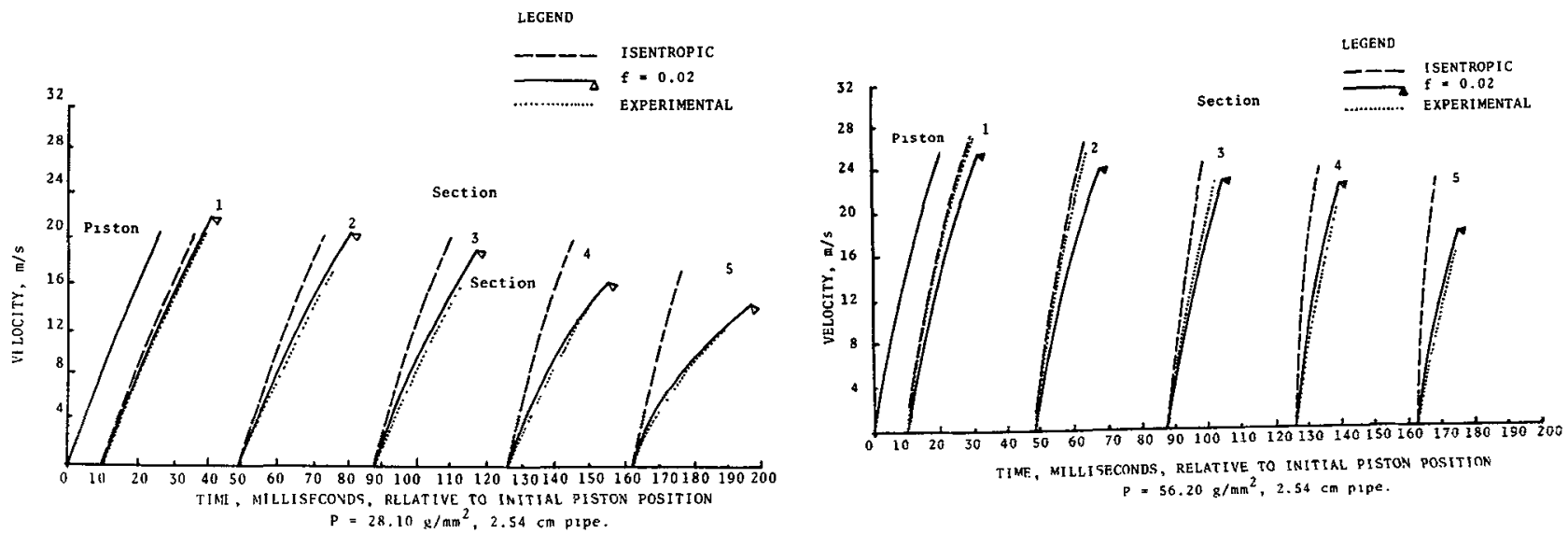

Figures $1-4$ : Comparison of Numerical Calculations With Experimenta1 Data for Burst Pressure.

piston velocity profile at the pipe inlet, theoretical results of wave propagation analyzed in terms of velocity profiles for isentropic process and frictional processes with four assumed values of frictional coefficient in each of the figures.

Specific comparison made between the two pipes is the relationship among attenuation coefficients $\alpha$, pipe distance $X$ and the energy diffusion expressed in terms of energy flux ration, $E / E_{0}$ as shown in Figure 5 . E denotes the energy flux on a time average contained in the pressure wave in propagation process and $E_{0}$ is the energy flux on a time average contained in the progressive wave at the origin of propagation.

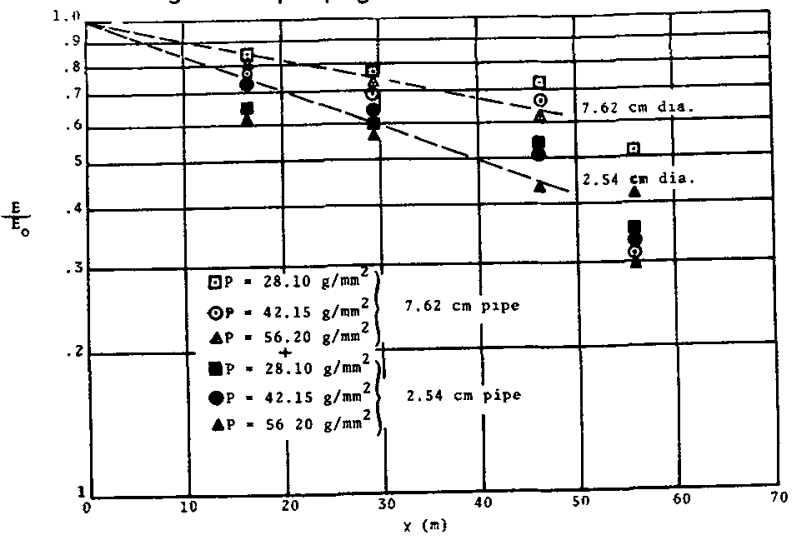

Figure 5 : Energy Flux Ratio Vs. Pipe Length.

The energy flux ratio may be approximated by

$$
\frac{E}{E_{0}} \frac{\frac{1}{T} \int_{0}^{T} v^{2} d t}{\frac{1}{T} \int_{0}^{T} 0 v^{2} d t}
$$

as a function of $x$. Values of $E / E_{0}$ were calculated from velocity profile data as functions of time in Figures 1 to 4 using Equation (1). Slopes of the lines averaged through plotted points in Figure 5 yield varied attenuation coefficients, $\alpha$ for the two pipes. The average values of $\alpha$ for 7.62 and $2.54 \mathrm{~cm}$ pipes are respectively $0.0102 \mathrm{~m}^{-1}$ and $0.0173 \mathrm{~m}^{-1}$ for the first $4 \mathrm{~g} \mathrm{~m}$ of the pipes. However, $\alpha$ appears to be the function of $x, s i-$ gnifying that the attenuation is non-linear. Comparison and Discussion of Data. - Since the energy flux ratio is suggested /4/ to be

$$
\frac{E_{0}}{E_{0}}=e^{-\alpha x}
$$

and

$$
\alpha=\frac{\omega^{2} \delta}{a^{3}}
$$

where $\omega$ is the angular or radian frequency, $\delta$ the diffusivity. Values of $\delta$ calculated from Equation (3) with $\omega=78.5 \mathrm{rad} / \mathrm{sec}$ and $a=350.52 \mathrm{~m} /$ sec are noted to be $71.29 \mathrm{~m}^{2} / \mathrm{sec}$ for $7.52 \mathrm{~cm}$ pipe and $121.11 \mathrm{~m}^{2} / \mathrm{sec}$ for $2.54 \mathrm{~cm}$ pipe.

Figure 5 reveals that the theory may be valid in a significant portion of the pipe except the section next to the pipe exit. The experimental evidence seems to demonstrate that the attenuation tend to increase along the pipe. The theoretical analys is was developed simply for the plane progressive wave propagating in a one-dimensional plane without consideration of the frictional effect along the pipe wall. Therefore, any prediction 
of the effects of pipe size and wall friction was not possible.

However, the experimental analys is evidently shows, through graphical presentation, that the effects of pipe geometry are pronounced on the attenuation characteristics for the type of wave propagation in the pipes studied.

The values of $\alpha$ and $\delta$ are considered rather high due to high humidity of about $80 \%$ relative in the atmosphere at the time of experimentation. But this factor of nature cannot be easily controlled, so is the temperature of the atmosphere. However, it might be decuced that the attenuation coefficient as well as diffusivity may not be a constant value in the process of non-linear wave propagation, and the exponential decay of energy flux in the wave seems to exhibit some nonlinearity.

\section{REFERENCES}

/1/ Shih C., "Non-linear Pressure Wave Propagation in Pipes", Proc., Interagency Symposium of University Research in Transportation Noise, Stanford, Calif., March 1973, pp 583-598.

12/ Shih C., "Attenuation Characteristics of Nonlinear Pressure Wave Propagation in Pipes", Proceedings, Fourth International Symposium on Non-linear Acoustics-IPC Science and Technology Press Ltd., August 1973.

/3/ Shit C., "Investigations of Scaling Characteristics for Defining Design Environments due to Transient Ground Winds and Near-field Nonlinear Acoustic Fields", Report NAS8-28249, UAH, UAH, Sept. 1973.

/4/ Linghthill M.J., "Surveys in Mechanics", Edited by G. K. Batchelor and R. M. Davis, Cambridge University Press, pp 250-351, 1956. 